\title{
Energy Analysis of Paddy Production in Konkan Region of Maharashtra
}

\author{
Pooja Rajendra Pawar* and S.V. Pathak \\ College of Agricultural Engineering and Technology, Dapoli, Maharashtra, India \\ *Corresponding author
}

\begin{abstract}
A B S T R A C T

\begin{tabular}{|l|}
\hline Ke y w or d s \\
Energy equivalent, \\
Energy analysis, \\
Energy efficiency \\
\hline Article Info \\
\hline Accepted: \\
07 November 2018 \\
Available Online: \\
10 December 2018 \\
\hline \hline
\end{tabular}

Energy analysis is essential for efficient management of the resources in agricultural production. The study was carried out on energy requirement and energy input output relationship of paddy production in konkan region of Maharashtra state. Different farm operations from land preparation to storage were considered for finding the energy consumption in paddy cultivation. Primary data were obtained through field survey. Data were collected from Agronomy field of Balasaheb Sawant Kokan Krishi Vidyapeeth, Dapoli in the year 2017-2018. The results revealed that energy consumed for paddy production was $34789.77 \mathrm{MJ} / \mathrm{ha}$. The net energy, specific energy, energy use efficiency, energy productivity and water productivity for paddy cultivation was found to be $86510.23 \mathrm{MJ} / \mathrm{ha}, 8.69 \mathrm{MJ} / \mathrm{kg}, 3.49,0.11 \mathrm{~kg} / \mathrm{MJ}$ and $0.40 \mathrm{~kg} / \mathrm{m}^{3}$. Fertilizers contributed highest share of input energy for paddy cultivation. The contribution of indirect energy $(71.54 \%)$ was higher than that of the direct energy $(23.27 \%)$. In direct energy, the highest share of diesel fuel (15.37\%) as well as in indirect energy chemical fertilizers $(56.71 \%)$ contributed highest share.
\end{abstract}

\section{Introduction}

Energy is a critical aspect of a national development process. Energy use in agricultural production has become more intensive due to the use of fossil fuel, chemical fertilizers, pesticides, machinery and electricity to provide substantial increases in food production. To achieve higher agricultural yields, more and more energy inputs like fertilizers, pesticides, tractors, threshers, tillage implements and high yielding varieties of seed are used. Direct energy is required to perform various tasks related to crop production processes such as land preparation, irrigation, intercultural, threshing, and harvesting and transportation of agricultural inputs and farm produce (Kennedy, 2000). It is seen that direct energy is directly used at farms and in the fields. Indirect energy, on the other hand, consists of the energy used in the manufacture, packaging and transport of fertilizer, pesticide, seed and farm machinery (Yaldiz et al., 1993). Calculating energy inputs of agricultural production is more difficult than in the industry sector due to the high number of factors affecting the production (Deike, 2008).

Konkan is coastal part of Maharashtra between Western ghat and Arabian Sea. The climate is hot humid with annual rainfall of 
$3500 \mathrm{~mm}$. This climatically condition proves paddy is major crop of this region. In Konkan, total 71.96 per cent farmers are marginal, 25.41 per cent are medium and 2.61 per cent farmers are large i.e. majority of farmer from marginal whose land holding is less than 1 ha. Due to this adverse condition for mechanization this district un-mechanized. Less mechanization indicates less energy used in field responsible to lower yield per ha (Mushtaq, 2009).

India ranks second in terms of total paddy production in the world, after China. Maharashtra is one of the important paddy producing states in India which ranks 14th in total production of paddy. The total area under paddy crop was 15.03 lakh hectares during 2015-16 which constituted 19.60 per cent of the total area under cereal crops (76.67 lakh hectares) in Maharashtra. Paddy covered 37.60 per cent of total cereals production in Maharashtra, accounted to 25.93 lakh tonnes during the year 2015-16. The average productivity of the state was $1.73 \mathrm{t} / \mathrm{ha}$ for the year 2015-16. In the Maharashtra state, paddy is grown in various districts with varying extent. However, the major paddy growing districts are Raigad, Palghar, Thane, Ratnagiri, Sindhudurg of Konkan region; Pune, Satara Sangli, Kolhapur districts of Pune division and Nashik, Nandurbar of Nashik division. In the Maharashtra state, paddy is grown in various districts with varying extent. However, the major paddy growing districts are Raigad, Palghar, Thane, Ratnagiri, Sindhudurg of Konkan region; Pune, SataraSangli, Kolhapur districts of Pune division and Nashik, Nandurbar of Nashik division (Socioeconomic Review and District Statistical Abstracts of the Thane, Raigad, Ratnagiri and Sindhudurg districts 2014-15).

After the collection of data it was found that, due to fragmentation and undulation of land in konkan region, least machinery for farm operations were used except primary and secondary tillage operation. Various field operations followed in paddy crop are done by manually. However, threshing operation is mechanized. In paddy cultivation the activity starts from the preparation of the soil for cultivation to harvesting and transportation operation. These operations were carried by using human, animal and tractor power sources (Mandal, 2002). It has large scope to increase the power availability per hectare in konkan region. The aim of this research was to determine energy use efficiency per hectare for the production of paddy, to assess the mechanization status of konkan region.

\section{Materials and Methods}

\section{Study and location}

The study depends on both secondary and primary data. For the purpose of collecting the primary data, the major techniques applied were observation and informal and formal information were collected. The survey method was used as a tool for data collection to study the energy consumption pattern. Data was collected from Department of Agronomy of Dr. BSKKV Dapoli.

Energy requirement of paddy crop was satisfied by using different types of energy resources, which falls under direct and indirect energy sources. The direct energy includes human labour, diesel fuel, gasoline, electricity and natural gas energy that are used in the production process and indirect energy consists of machinery, chemical fertilizer, seed and biocide energy. On the other hand, renewable energy consists of human labour and seed and non-renewable energy inclusive machinery, diesel fuel, gasoline, natural gas, electricity, biocide and chemical fertilizer. Renewable energy used to describe energy sources that are replenished by natural processes on a sufficiently rapid time-scale. 
The direct energy sources include human, animal, fuels (petrol and diesel), etc. and indirect include chemicals (fertilizers and pesticides), seeds, manure, biomass, water, etc. To determine energy requirement of paddy crop, it was divided in two main groups i.e. input and output energy. The physical units of different inputs and output were converted into energy units by using the respective conversion factori.e. energy equivalent (Alipour,2012) (Singh,1992).The respective energy equivalents are given in Table 1.

\section{Energy sources and terminologies}

\section{Energy}

The term 'energy' has been derived from the Greek word energia meaning capacity to do work. Energy is a primary input in the production of goods and services. Energy was used as a fuel for household cooking; now energy is a major input in sectors such as industry, commerce, transport and telecommunications.

\section{Gross energy}

Gross energy refers to the energy content of fuels and farm inputs. The energy content of each fuel and farm input is multiplied by their respective quantities. The energy content of the fuels and inputs is converted into energy values in Mega Joules (MJ) and Giga Joules (GJ) in this study.

\section{Energy productivity}

Energy productivity, intensity and efficiency were worked out for various farm categories and crops on per hectare basis. Energy productivity was calculated by dividing the yield in $\mathrm{kg}$ by input in MJ. The formula is as follows:
Energy Productivity $=\frac{\text { Output in kg }}{\text { Input in MJ }}$

(Singh, 1992)

This formula is used to estimate how much of output is produced by one unit of energy input.

\section{Energy intensity}

Energy intensity was worked out by dividing the input in MJ by the yield in $\mathrm{kg}$. The formula is as follows:

Energy Intensity $=\frac{\text { Input in MJ }}{\text { Output in MI }}($ Singh, 1992)

\section{Energy efficiency}

Energy efficiency was found out by dividing the energy output by energy input. The formula is as follows:

Energy Efficiency $=\frac{\text { Energy output in MJ }}{\text { Energy input in MJ }}$

(Singh, 1992)

Specific energy $=\frac{\text { Total energy input }(\mathrm{MJ} / \mathrm{ha})}{\text { Grain yeild } \mathrm{kg} / \mathrm{ha}}$

Water productivity $=$

(Singh,1992)

$\frac{\text { Grainyield }(\mathrm{kg} / \mathrm{ha})}{\text { Amount of water applied cubic m.per ha }}$

(Alipour,2012)

Net energy = Energy output $(\mathrm{MJ} / \mathrm{ha})-$ Energy input (MJ/ha) (Alipour, 2012).

\section{Results and Discussion}

The results have been encapsulated in following sections

\section{Input-output energy analysis}

Table 3 elaborates average energy consumption for paddy production. Total average input and output energy were 
34789.77 and $121300 \mathrm{MJ} / \mathrm{ha}$, respectively. The highest energy used in paddy production belonged to fertilizers(including $\mathrm{N}, \mathrm{P}_{2} \mathrm{O}_{5}, \mathrm{~K}_{2} \mathrm{O}$ and F.Y.M.) energy which accounted was about $19730.60 \mathrm{MJ} / \mathrm{ha}$ of total input energy consumption. Fuel input plays an important role in total energy consumption for paddy production. Fertilizer energy was followed by fuel energy was about $5349.50 \mathrm{MJ} / \mathrm{ha}$. According to Singh et al., (1998) research results, energy used in the production of chemical fertilizer accounts for about $40 \%$ of total energy used in agricultural production in developed countries. Energy consumed by water for irrigation purpose was about 4000 $\mathrm{MJ} / \mathrm{ha}$. Energy input from labour (male and female) were $2761.60 \mathrm{MJ} / \mathrm{ha}$. In konkan region, most of farm operations are done manually such as transplanting, intercultural etc. Energy consumption for machinery and biocide were 1160 and $1200.07 \mathrm{MJ} / \mathrm{ha}$, respectively.

\section{Energy forms and indices in paddy production}

Table 4 shows energy indices of paddy production and the forms of energy inputs as direct, indirect, renewable and non-renewable energy. The results indicated the average energy use efficiency were 3.48. Energy productivity, specific energy and net energy were $0.11 \mathrm{~kg} / \mathrm{MJ}, 8.69 \mathrm{MJ} / \mathrm{kg}$ and 86510.23 $\mathrm{MJ} / \mathrm{ha}$. Direct, indirect sources of energy were $8111.1,26678.67, \mathrm{MJ} / \mathrm{ha}$ respectively.

Table.1 Energy equivalents of inputs and output in paddy production

\begin{tabular}{|c|c|c|c|}
\hline Sr. No. & Parameters & Unit & Energy Equivalent \\
\hline \multicolumn{4}{|c|}{ Input Parameters } \\
\hline 1. & $\begin{array}{l}\text { Human labour } \\
\text { Male } \\
\text { Female }\end{array}$ & $\begin{array}{l}\mathrm{h} \\
\mathrm{h}\end{array}$ & $\begin{array}{l}1.96 \mathrm{MJ} / \mathrm{h} \\
1.57 \mathrm{MJ} / \mathrm{h}\end{array}$ \\
\hline 2. & Machinery & $\mathrm{h}$ & $62.7 \mathrm{MJ} / \mathrm{h}$ \\
\hline \multirow[t]{2}{*}{3.} & Chemical fertilizers & & \\
\hline & $\begin{array}{l}\text { Nitrogen } \\
\text { Phosphate } \\
\text { Potash }\end{array}$ & $\begin{array}{l}\mathrm{kg} \\
\mathrm{kg} \\
\mathrm{kg}\end{array}$ & $\begin{array}{l}60.60 \mathrm{MJ} / \mathrm{h} \\
11.1 \mathrm{MJ} / \mathrm{h} \\
6.7 \mathrm{MJ} / \mathrm{h}\end{array}$ \\
\hline 4. & Diesel & lit & $56.31 \mathrm{MJ} / \mathrm{Kg}$ \\
\hline 5. & F.Y.M. & $\mathrm{kg}$ & $0.30 \mathrm{MJ} / \mathrm{h}$ \\
\hline 6. & Paddy Seed & $\mathrm{kg}$ & $14.7 \mathrm{MJ} / \mathrm{h}$ \\
\hline \multirow[t]{2}{*}{5.} & Plant Protection & & \\
\hline & $\begin{array}{l}\text { Granular } \\
\text { Liquid }\end{array}$ & $\begin{array}{l}\mathrm{kg} \\
\text { lit }\end{array}$ & $\begin{array}{l}120 \mathrm{MJ} / \mathrm{kg} \\
0.102 \mathrm{MJ} / \mathrm{lit}\end{array}$ \\
\hline \multicolumn{4}{|c|}{ Output Parameters } \\
\hline 1. & Grain & $\mathrm{kg}$ & $14.7 \mathrm{MJ} / \mathrm{kg}$ \\
\hline 2. & Straw & $\mathrm{kg}$ & $12.50 \mathrm{MJ} / \mathrm{kg}$ \\
\hline
\end{tabular}


Table.3 Computation of energy inputs and outputs paddy crop (MJ/ha)

\begin{tabular}{|l|c|c|c|c|c|}
\hline \multicolumn{1}{|c|}{ Parameters } & Unit & \multicolumn{1}{c|}{$\begin{array}{c}\text { Energy } \\
\text { Equivalent }\end{array}$} & $\begin{array}{c}\text { Energy } \\
\text { Consumed } \\
\text { (per hectare) }\end{array}$ & $\begin{array}{c}\text { Energy } \\
\text { MJ }\end{array}$ & \% \\
\hline & & & & & \\
\hline
\end{tabular}



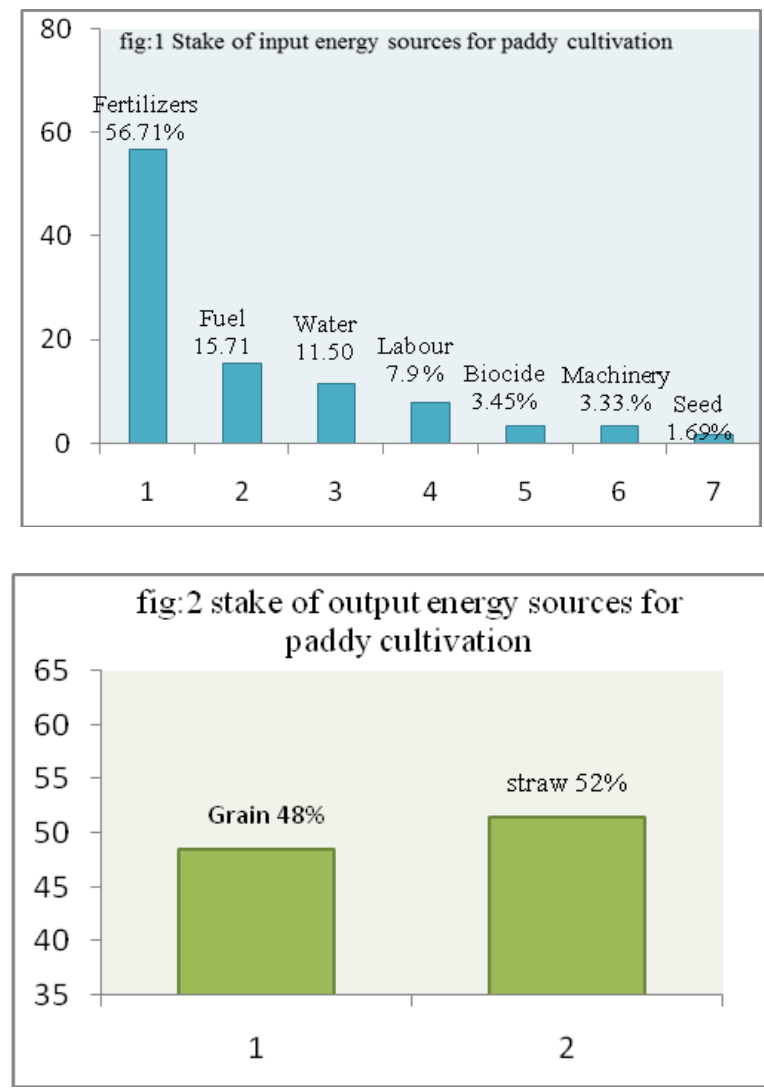

Fig-3 Stake of direct energy sources in paddy
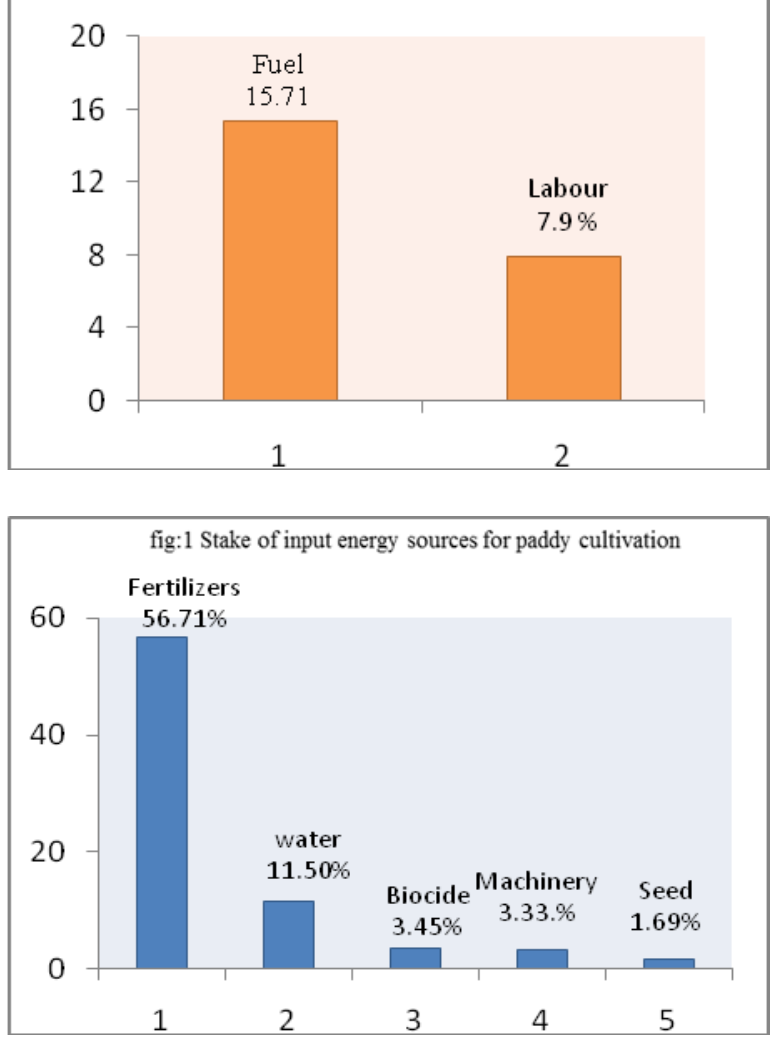
Table.4 Energy forms and indices in paddy production

\begin{tabular}{|l|l|l|}
\hline Particulars & Unit & $\begin{array}{l}\text { Unit per } \\
\text { ha }\end{array}$ \\
\hline $\begin{array}{l}\text { Energy use } \\
\text { efficiency }\end{array}$ & & 3.48 \\
\hline $\begin{array}{l}\text { Energy } \\
\text { productivity }\end{array}$ & $\mathrm{kg} / \mathrm{MJ}$ & 0.11 \\
\hline Specific energy & $\mathrm{MJ} / \mathrm{kg}$ & 8.69 \\
\hline Net energy & $\mathrm{MJ} / \mathrm{ha}$ & 86510.23 \\
\hline Direct energy & $\mathrm{MJ} / \mathrm{ha}$ & 8111.1 \\
\hline Indirect energy & $\mathrm{MJ} / \mathrm{ha}$ & 26678.67 \\
\hline
\end{tabular}

From figure 1 shows the percentage of input energy sources for paddy cultivation. Fertilizers consumed highest energy which is followed by water for irrigation, fuel (diesel), labour requirement, machinery and biocide. Energy consumed by labour are more as compared to farm machineries as paddy cultivation is done by traditional method in these region. There is wide scope to develop small machineries which can be efficiently operated in fragmented fields of this region and which can run by means of human, animal or by means of fuel.

Figure 2 shows the percentage of output sources of energy for paddy cultivation. Energy consumed by straw was more than the grain required for field operations.

Figure 3 shows the percentage of direct sources of energy for paddy cultivation. Energy consumed by fuel was more than the labour required for field operations. Practically, it was seen that, in most of the cases the fuel was used for tillage, puddling and threshing operation.

Figure 4 shows the share of indirect energy sources for paddy cultivation which is categorized under input energy sources. Fertilizers shares highest consumption of energy which was followed by water requirement, machinery, biocide and seed.
In conclusion, the study reveals that, in konkan region due to fragmentation, undulating of land was hindrance for use of machinery in the region hence, imperfectly mechanized. Energy consumed by had been found very limited and came only from human powered hand tools and tillage implement, which had a share of about 3\%$4 \%$. It is essential to use modern technologies and new machineries for post-harvest operations to decrease high amount of energy usage in paddy production. There is scope and need to develop small scale machinery which reduces human drudgery encountered during operation of hand tools and heavy implements.

\section{Acknowledgement}

The authors are thankful to Department of Agronomy, Dr. BSKKV, Dapoli for providing support for conducting the survey.

\section{References}

Alipour, A., Veisi, H., Darijani, F., Mirbagheri, B. and Behbahani, A.G. (2012).Study and determination of energy consumption to produce conventional rice of the Guilan province. Res. Agric. Engg., 58 (3): 99106.

Deike, S., Pallutt, B. and Christen, O. (2008). 
Investigations on the energy efficiency of organic and integrated farming with specific emphasis on pesticide use intensity. European J. Agron., 28 (3), 461-470.

Mandal, K.G., Saha, K.P., Ghosh, P.K., Hati, K.M. and Bandyopadhyay, K.K. (2002). Bioenergy and economic analysis of soybean-based crop production systems in central India. Biomass \& Bioenergy, 23: 337-345.

Mushtaq, S., Maraseni, T.N., Maroulis, J. and Hafeez, M. (2009). Energy and water trade-offs in enhancing food security: A selective international assessment. Energy Policy, 37: 3635- 3644.

Nassiri, S.M. and Singh, S. (2009). Study on energy use efficiency for paddy crop using data envelopment analysis (DEA) technique. Appl. Energy, 86: 13201325.

Kennedy S. Energy use in American agriculture. Sustainable energy.2000

Singh, S. and Mittal, J.P. (1992). Energy in production agriculture. Mittal Publications New Delhi, India.

Socio-economic Review and District Statistical Abstracts of the Thane, Raigad, Ratnagiri and Sindhudurg districts 2014-15.

Yaldiz O, Ozturk H, Zeren Y, Bascetincelik A. Energy usage in production of field crops in Turkey. In: Proceedings of 5th International Congress on Mechanization and Energy Use in Agriculture; 1993 Oct 11e14; Kusadas.

\section{How to cite this article:}

Pooja Rajendra Pawar and Pathak, S.V. 2018. Energy Analysis of Paddy Production in Konkan Region of Maharashtra. Int.J.Curr.Microbiol.App.Sci. 7(12): 527-534. doi: https://doi.org/10.20546/ijcmas.2018.712.066 